\title{
City Branding as a Tool for Urban Regeneration: Towards a Theoretical Framework
}

\author{
Viktorija Prilenska, Delft University of Technology
}

\begin{abstract}
This paper studies the concept of city branding in general and its objectives, and examines the most common branding strategies - the creative city and the experience city. Further on, the paper elaborates on the notion of image-reality consistency and explores the role of flagship developments in branding and urban regeneration. Consequently, a strong casual link between city branding and urban regeneration is established.
\end{abstract}

KEYWORDS: city branding, creative city, experience city, flagship developments, urban regeneration.

In the current economic paradigm, which is described as a transition period from the industrial to knowledge economy, such factors as proximity to markets and supply of labour do not play a significant role $[4 ; 11]$. Furthermore, former industrial cities try to reduce their dependence on manufacturing and develop alternative sources of income, such as high-tech industries or leisure consumption $[4 ; 11 ; 18]$. However, industrial city image is a major obstacle on the way to economic diversification [13; 18].

Furthermore, the shift towards the knowledge economy has made firms and labour markets extremely flexible and fluid [15]. Industries and workers relocate to the cities which provide better business and living opportunities [4; 12]. The growing mobility of financial and human resources exacerbates the intraurban competition. Nowadays, cities increasingly have to compete for inward investment, tourists and new residents.

The image of the city plays a significant role in the location choices made by investors, firms and individuals [18]. However, it is not enough to create an attractive image, it is essential to make it well-known locally and internationally. Under these circumstances, city branding becomes an exceptionally important tool for image-building and image-communication $[6 ; 8]$.

This paper argues that in addition to competitive advantages city branding stimulates the urban regeneration of the city. Indeed, image-reconstruction is impossible if there are no tangible changes in the place quality $[6 ; 7 ; 8 ; 13]$. "An image campaign without any improvement in reality would be hollow and short-lived" [13, 347]. By discussing the notion of city branding and its goals, commonplace branding strategies, as well as image-reality consistency and the role of flagship developments in city branding and urban regeneration, the paper builds a strong casual relationship between city branding and urban redevelopment.

There is an on-going debate weather city authorities should invest into city branding rather than pursue traditional urban and economic development strategies, such as infrastructure improvement or tax breaks $[4 ; 14 ; 15]$. However, it is not the aim of the paper to discuss the efficacy of city branding in comparison to other development strategies. Instead, the paper is based on the statement that traditional development strategies have proved not to be as productive anymore as they used to be $[3 ; 4]$.

\section{City Branding and its Goals}

The brands add certain value to products, contribute into construction of consumer identity and link the consumer with the community of brand users $[1 ; 8]$. Therefore, out of various products with more or less the same attributes, a product with a brand identity is likely to gain a competitive advantage [7]. Although cities are not products, city branding "has been practised consciously or unconsciously for as long as cities have competed with each other" [8, 510]. Furthermore, cities or places need to be promoted as brands to be "recognised as existing", "perceived ... as possessing qualities superior to those of competitors" and "consumed in a manner commensurate with the objectives of the [city or] place" [8,510].

The notions of city brand and branding do not have clear definitions yet. Kavaratzis [6] argues that cities resemble corporate brands because they are complex entities which deal with multiple identities, address various stakeholders and have social responsibilities. Therefore, cities can be promoted in a similar way to corporate brands. Like products which are sold under an umbrella brand, various aspects of cities can be marketed. For example, a city can be promoted as a place to live, to work, destination to visit and opportunity to invest [8].

City branding has various regional variations. While in the US city branding aims to stimulate economic growth, in Europe it is aimed to improve all aspects of socio-economic well-being [13]. Kavaratzis [7], in turn, emphasizes that the ultimate goal of all city branding related activities is to improve the quality of life for local residents.

City branding is generally understood as a whole set of actions to build the positive image of the city and communicate it among various target groups via visuals, narratives and events locally and internationally to gain a competitive advantage among other cities $[7 ; 18]$. The objectives of city branding are: to attract inward investment and tourists and to "reinforce local identity and identification of the citizens with their city" [6, 70]. Thus, city branding is a means to improve "external" and "internal" images of the city [18].

According to Kavaratzis and Ashworth [8] there are three types of place branding: 1) the name of geographic location as a brand name, 2) co-branding of place and product and 3) branding of a place per se. In relation to this typology, it is necessary to mention the two city branding strategies that have gained exceptional popularity recently, the "creative city" and the "experience city" strategies $[4 ; 11 ; 14 ; 18]$. These strategies involve the second and the third types of place branding and will be discussed further on. 


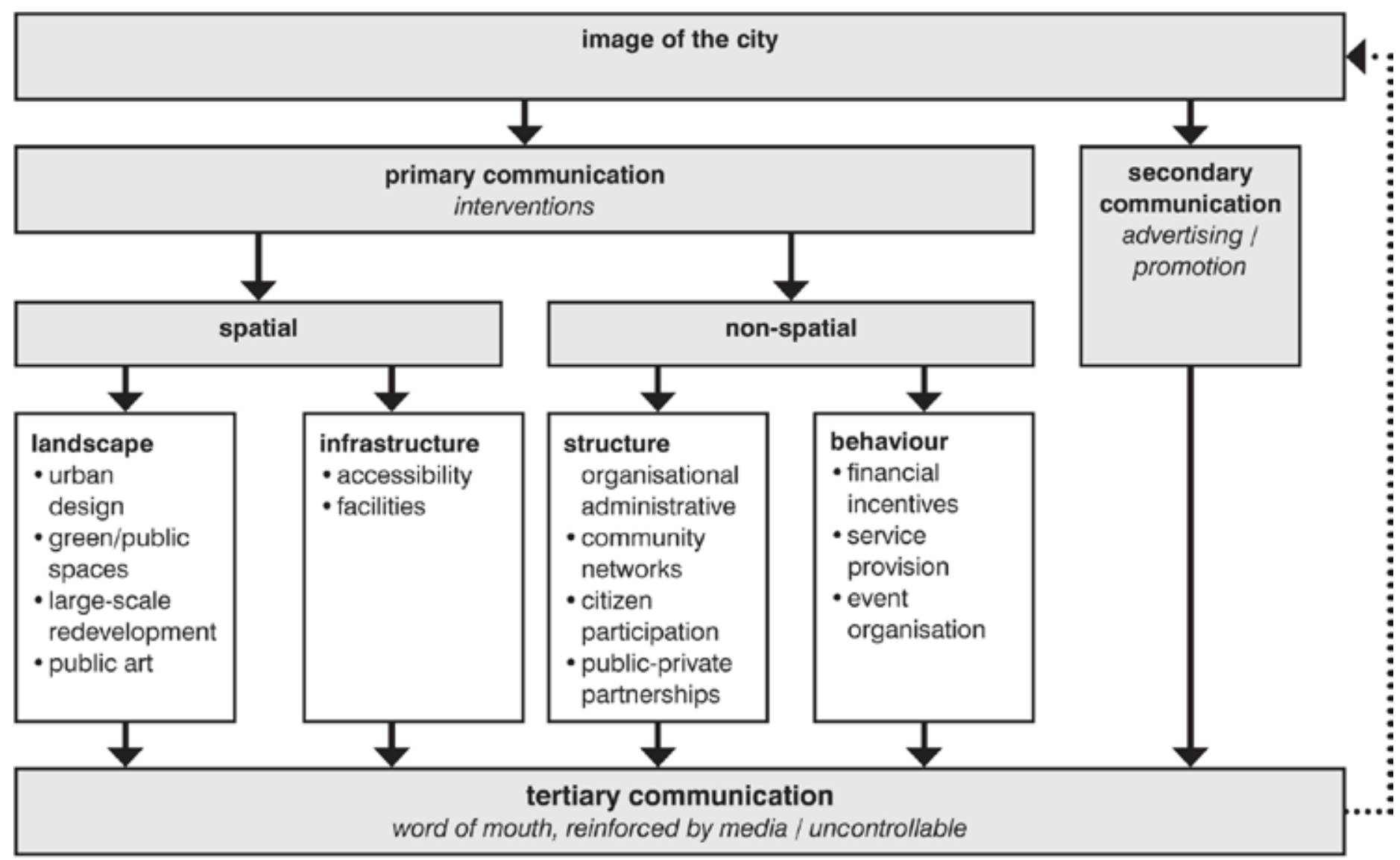

Fig. 1. City image communication, adopted from Kavaratzis. [6]

\section{Creative City Strategy}

The goals of city branding are to foster economic development of the city and to improve well-being of its residents. The driving force of economic progress in the current economic paradigm is human capital, namely educated, skilful and productive people $[4 ; 5 ; 12 ; 15]$. In other words, there is a strong correlation between regional economic growth and high concentration of qualified workers in the area $[4 ; 5 ; 12]$.

Florida [4] has supplemented the human capital theory by specifying the type of human capital, the creative class, as the one contributing to economic progress, and by defining the factors which shape location choices of these people. Creative people are attracted by "creative centres", the cities that "have high concentrations of creative economic outcomes" [4, 8], namely innovations and high-tech industries, are diverse, tolerant and provide a variety of high-quality experiences. In other words, "creative cities" are the centres of technology, talent and tolerance. Furthermore, he stated that there is a causality between a high percentage of the creative class of the total workforce and subsequent economic growth of the city [3].

The creative class theory, especially the causal relationship between educated and skilful people and economic progress was statistically proved in the study of the Danish creative class [12]. The survey indicated that some of high-tech industries relocate to be able to recruit highly-qualified employees. Through a number of focus interviews the location choice factors essential for these workers were listed. Apart from employment opportunities and career prospects, the creative class values are:

1. qualitative and affordable housing;

2. public amenities and services;

3. short travel times;

4. lifestyle opportunities;

5. cultural opportunities;

6. quality of city spaces, such as well maintained green and public spaces, access to water, good architecture etc.

Most of these factors are either spatial, or have spatial implications. Moreover, the report emphasized that educated and skilful people prefer to live in satellite cities, because these cities provide the "other quality of life such as green spaces, forest and seaside" $[12,88]$. Therefore, the quality of urban environment is of utmost importance for creative workers [3].

Despite the criticism $[5 ; 14 ; 15]$, the creative class theory gained popularity among city authorities. The notion of the "creative city" and associated urban redevelopment became widely used in city branding [14; 18].

\section{ExPerience City Strategy}

Only a few cities, however, are able to turn into creative centres. Many other cities have insufficient resources for knowledge-based development, in other words they do not have a "technology" component [11]. These cities can benefit from the experiences they offer, for example the ones based on authenticity and nature $[11 ; 12]$. In these circumstances cities benefit from consumption 


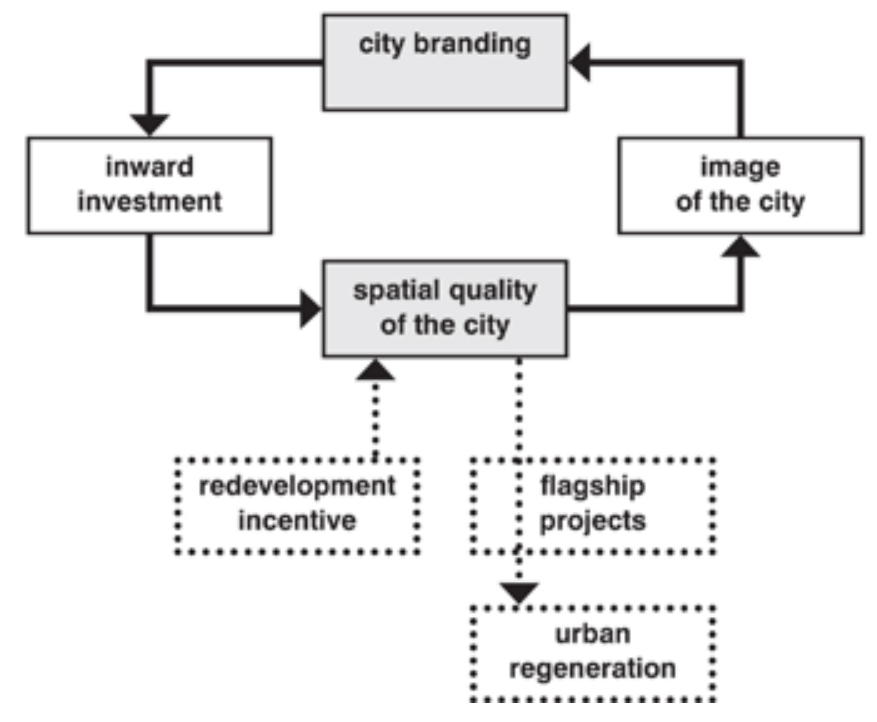

Fig. 2. Mutual dependency of city branding and spatial quality.

which becomes "a driver of growth" $[11,841]$ and the creative class "because of its potential to consume" $[18,381]$.

Lorentzen [11] argues that the city per se along with "placebound experiences" becomes the object of production and consumption and is branded and co-branded as a product. The relation of certain experience-product to a particular city or place becomes part of the experience-product identity and in this way increases the value of the experience-product. Therefore, place quality is a determinative factor of success. According to Lorentzen "place-bound experiences" include:

1. events, for example, Salzburg Festspiele (Austria) and Bayreuth Festspiele (Germany);

2. activities, such as shopping, hiking, sports, handicraft and artistic activities;

3. services, like theme restaurants, wellness centres, art galleries, theatres and cinemas;

4. places as a "stage" for activities and in themselves, such as castles, squares, parks, woods, beaches, museums, malls and whole cities.

The concept of "experience city" is "a window of opportunity" for the cities which due to their size, location or historically do not have potential for developing high-tech industries [11].

To sum up, there are two widely spread city branding concepts: the "creative city" and the "experience city". While the idea of "creative city" may incorporate the "experience city" notion, the "experience city" concept provides economic growth opportunities for cities with limited high-tech industry development options. Both branding concepts have spatial implications, which require adjustments of the physical structure of the city. In the "creative city" paradigm the pleasant urban environment strengthens the competitive advantage of the city, while in the "experience city" the urban quality is a key attraction factor.

\section{IMAGe-Reality Consistency}

The success of a branding campaign depends on the consistency of city image and reality $[6 ; 13]$. The new city image should be reflected in the spatial structure of the city [18]. On the example of the city of Glasgow, Paddison [13] illustrates the disputable outcomes of the marketing campaign of the 1980s. Although urban tourism has increased significantly, the attractiveness of the city for potential residents has not improved due to a huge image-reality gap between widely marketed images and degraded suburbs.

Thereby, city branding consists of spatial and communication components. Kavaratzis [6] calls it primary, secondary and tertiary communication (Figure 1). Primary communication, in turn, is divided into spatial and non-spatial (the author's classification). Spatial communication is a set of interventions aimed to improve the physical quality of the city, such as large-scale redevelopment and infrastructure projects. Non-spatial communication deals with enhancement of social environment, service provision and event organisation. The secondary communication is promotion of the new city image by the interested parties. Tertiary communication is "a word of mouth", the reflection on the city image reinforced by media or competitor cities, which can not be influenced. Any statements about the image-reality gap spread through the tertiary communication.

Therefore, it is necessary to improve both spatial and nonspatial components of the urban environment prior to a branding campaign. Spatial changes, in turn, are essential, because they provide visual images used in city branding [18]. The impact of branding campaigns on spatial quality of the city is summarized as a closed-loop diagram (Figure 2), where an attractive urban environment generates a positive image of the city which is exploited in urban branding. As a result of a branding campaign, the city attracts tourists, investors and new residents and strengthens its local identity. All these actors bring extra financial resources which, in turn, can be invested to improve spatial quality of the city. Flagship project development can be one of the techniques to improve the urban environment because it is able to catalyse further regeneration process. This technique will be discussed in the following section.

\section{Flagship Developments and Urban Regeneration}

According to Kavaratzis [6] there are three techniques of urban branding that have gained popularity among city authorities recently:

1. personality related branding, such as Gaudi architecture in Barcelona;

2. development of flagship projects, such as Guggenheim museum in Bilbao;

3. organisation of hallmark events, such as Bayreuth Festival in Germany.

Although, all the three techniques have certain spatial implications, flagship project development has the most evident spatial expression. Furthermore, it is argued that flagship projects are powerful urban regeneration tools [16; 17]. Indeed, these projects "transform the area in two ways: first, by their own presence, and second, as catalysts of additional capital investment and the attraction of consumption" [17, 171]. It is important to emphasize that flagship developments are not restricted exclusively to architecture icons, but include a wide range of urban projects which are beneficial for public and are capable to bring life into unused spaces, such as, for instance, open air swimming pool, skateboarding park or city beach. Furthermore, 
these projects can be financed to a large extent by private sector or local community. In case of private investment, however, public interests must be considered. The purpose of some flagship projects is pure branding, as in case of Frederikshavn Palm Beach [10]; other flagship projects are developed with multiple objectives including branding as one of them, as in case of Oslo Opera House [16] and Golden Angel in Prague [17].

For the Frederikshavn Palm Beach project exotic palm trees were planted on the city beach on the Baltic Sea coast. The Beach became a brand and a major attraction for locals and tourists. It launched incentives for the construction of a new pier and water playing facilities and for the holiday resort development [10].

Oslo Opera House is the first project of a large-scale urban regeneration plan aimed to redevelop a run-down industrial area. It is argued that, due to the successful public space developed as part of the project, the area was returned to the citizens [16].

Temelova [17] argues that the Golden Angel project has catalysed redevelopment of brownfield sites, renovation of existing buildings and enhancement of public spaces in the area. Furthermore, "the whole neighbourhood became perceived as a secure location to invest in" [10: 178], due to the success of the Golden Angel itself and because of "celebrity architect" Jean Nouvel and "internationally recognized developer" ING Group involved in the project.

All the above-mentioned flagship project examples turned out to be successful and have launched further redevelopment of the area. However, Temelova [10] argues that despite being strong promotional tools both locally and internationally, the outcome and success of flagship projects may significantly differ across the cities. Smith and von Krogh Strand [16] emphasize that flagship projects improve the spatial quality of the city on the condition that public interests are recognised.

\section{CRITICISM}

The implementation of city branding and associated urban redevelopment are criticised for production of standardised, sanitised and gentrified urban environments [1; 14]. It is argued that city authorities use commonplace urban design and branding methods which result into "sameness" [6;14], namely "up-scale streetscapes, expensive shopping facilities, and well-appointed residential enclaves" [15,4]. Furthermore, urban regeneration projects usually lead to the increase in rents and land values in the area, therefore less well-off residents and local businesses are squeezed out. This way socio-spatial segregation is increased and social tensions are sharpened $[1 ; 14 ; 15 ; 17]$.

The notion of "creative city" undergoes the most severe criticism in this context. "Creative centres" are the epitome of a "dual city", where the highly qualified workers co-exist with the "masses of low-wage low-skill workers" [4; 15]. Moreover, "creative centres" epitomize gentrified "enclaves in an urban landscape where poverty and social deprivation still widely prevail" $[15,12]$. To ameliorate possible negative effects of city branding, city authorities need to focus on unique features of the city and stimulate local business incentives and citizen participation in decision making $[1 ; 6]$.

Furthermore, large flagship developments are often criticised for being over expensive, however, in case Frederikshavn Palm
Beach the expenses were as high as required for plantation and maintenance of palm trees and arrangement of some basic public facilities. The value of the project was in the innovative idea of tropical plants in moderate climate on the cold beach [11]. In case of the Golden Angel project all construction works were financed by private investors, while the municipality paid the improvement of public spaces only [17].

\section{CONCLUSIONS}

To sum up, city branding is a complex multi-faceted notion which consists of multiple place brands which, in turn, address various stakeholders. It is a set of actions aimed to improve the competitiveness of the city internationally and reinforce the identification of local residents with the city. Although the object of branding is the image of the city rather than the city per se, the image should be derived from reality. Therefore, city branding starts with tangible interventions. These interventions include both spatial and non-spatial aspects, such as redevelopment of the urban tissue, community building, service provision and event organisation. The new image attracts tourists, investors and new residents, who bring additional financial resources, which, in turn, boost economic development of the city and can be invested into new interventions.

Commonplace city brands are the "creative city" and the "experience city". The latter notion represents development opportunities for those cities which do not have enough hightech potential to become "creative centres". The concepts of "creative city" and "experience city" result into a certain urban form, which, on the one hand, is consumption oriented, and, on the other hand, is of a human scale. Both concepts often involve large-scale urban regeneration projects to meet the demands of target audiences. While in the "creative city" qualitative urban environment is an essential supplement to the employment and career opportunities, in the "experience city" it is a primary attraction element, an experience product or the "stage" for experience events, activities and services.

Ambitious urban redevelopment projects start with flagship projects, which are simultaneously powerful place branding tools and catalysts for further regeneration. The flagship projects are often promoted locally and internationally, as in case of Oslo Opera House, to gain public interest and attract investment to the area and this way to boost its further development. Local residents often benefit from the spin-off effects generated by flagship projects, such as improvement of public spaces or renovation of the existing housing stock.

Although the concepts of city branding and associated urban redevelopment are often criticised for being the cause of clichéd environments and social bifurcations, the benefits are obvious, and the negative effects may be alleviated by specific city policies. 


\section{REFERENCES}

1. Chatterton, P., Hollands, R. Theorising urban playscapes : Producing, regulating and consuming youthful nightlife city spaces. Urban Studies, 2002, No. 39, p. 95-116.

2. Cybriwsky, R. Changing patterns of urban public space : Observations and assessments from the Tokyo and New York metropolitan areas. Cities, 1999, No. 16 , p. 223-231.

3. Florida, R. The rise of the creative class: why cities without gays and rock bands are losing the economic development race [online]. Washington Monthly, 2002 [cited 19.12.2011]. www.washingtonmonthly.com

4. Florida, R. Cities and the creative class. City \& Community, 2003, No. 2, p. 3-19.

5. Glaeser, E. L. Review of Richard Florida's "The Rise of the Creative Class" [online]. Creative Class Group, 2004 [cited 20.02.2012]. www. creativeclass.com

6. Kavaratzis, M. From city marketing to city branding: Towards a theoretical framework for developing city brands. Place Branding and Public Diplomacy, 1 (2004), p. 58-73.

7. University of Groningen, From City Marketing to City Branding: An Interdisciplinary Analysis with Reference to Amsterdam, Budapest and Athens (PhD Dissertation by M. Kavaratzis, 2008). 214 p.

8. Kavaratzis, M., Ashworth, G. J. City branding : An effective assertion of identity or a transitory marketing trick? Tijdschrift voor Economische en Sociale Geografie, 2005, No. 96, p. 506-514.

9. Konijnendijk, C.C. Green cities, competitive cities - promoting the role of green space in city branding. 22nd IFPRA World Congress : quality services - parks, recreation and tourism. Hong Kong, China, November 15-18, 2010.

10. Lorentzen, A. Knowledge Networks in the Experience Economy : An Analysis of Four Flagship Projects in Frederikshavn (Center for Regional Udvikling). Aalborg: Department of Development and Planning, 2008. 32 p.

11. Lorentzen, A. Cities in the experience economy. European Planning Studies, 2009, No. 17, p. 829-845.

12. Lorenzen, M. Knowledge city models: Lessons from a study of the Danish creative class. The 3rd Knowledge Cities World Summit : from theory to practice (Melbourne, Australia, November 16-19). Melbourne, 2010, p. 363-390.

13. Paddison, R. City marketing, image reconstruction and urban regeneration. Urban Studies, 1993, No. 30, p. 339-350.

14. Peck, J. Struggling with the creative class. International Journal of Urban and Regional Research, 2005, No.29, p. 740-770.

15. Scott, A. J. Creative cities: Conceptual issues and policy questions. Journal of Urban Affairs, 2006, No. 28, p. 1-17.

16. Smith, A. Von Krogh Strand, I. Oslo's new Opera House : Cultural flagship, regeneration tool or destination icon? European Urban and Regional Studies, 2011, No.18, p. 93-110.

17. Temelová, J. Flagship developments and the physical upgrading of the post-socialist inner city : The Golden Angel project in Prague. Geografiska Annaler, Series B : Human Geography. 2007, No. 89, p. 169-181.

18. Vanolo, A. The image of the creative city: Some reflections on urban branding in Turin. Cities, 2008, No. 25, p. 370-382.

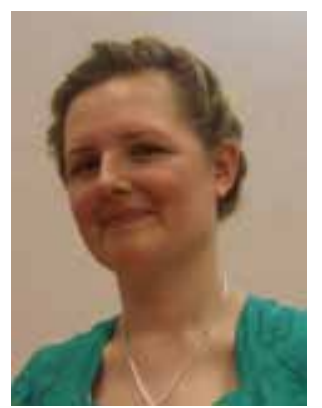

Viktorija Prilenska (Riga, 1985), B. arch. (Riga Technical University, 2008), Dip. arch. (Riga Technical University, 2010, with distinction), M. Sc. in architecture, urbanism and building sciences (Delft University of Technology, 2012; thesis Towards a Green Metropolis : Designing a Waterfront in Riga; mentors prof. ir. H. Bekkering, and ir. S. Nijhuis). SUPPORT $\mathrm{COACH}$ at International Office of Delft University of Technology (2012), $\mathrm{COACH}$ at International Office of Delft University of Technology (2011), ARCHITECT TECHNICIAN at architecture offices Kubs and Virtu. Participated in several scientific conferences.

Publications:

- Prilenska V. Riots in Riga. Atlantis : Magazine by Polis - Platform for Urbanism. Delft University of Technology, 2011, Vol. 22, No. 1, p. 20-21.

- Prilenska V., Bērziņš E. The use of natural coastal erosion process for island shaping at Cape of Bernāti = Dabīgas jūras krasta erozijas procesa izmantošana salas veidošanai Bernātu ragā. RTU 51 Student Scientific and Technical Conference Proceedings. Riga Technical University, 2010, Vol. 1, p. 8.

- Prilenska V., Bringkis J. Social housing = Sociālais mājoklis. RTU 49 Student Scientific and Technical Conference Proceedings. Rīga: RTU, 2008, Vol. 1, p. 14.

Current and previous research interests: city branding, intercity competition, creative cities, recreational space networks in cities, tools for measuring recreational space provision in cities, water management, coastal erosion, social housing.

Member of TU Delft Urbanism and Landscape Architecture student society Polis.

\section{Contact Data}

Viktorija Prilenska

Phone: +371 26340187

E-mail: vprilenska@gmail.com

Acknowledgements: Anna Maria Fernandez-Maldonado and Remon Rooij for their guidance in the developing of this paper. 